\title{
高速引張り試験による AFRP の動的特性 Dynamic Behavior of AFRP under Tensile Impact Force
}

\begin{tabular}{|c|c|c|c|}
\hline ) & 渡邊 & 谷正 & （三重大院） \\
\hline & 佐脇 & 豊 & (三重大) \\
\hline
\end{tabular}

Hiromasa WATANABE, Eitoku NAKANISHI, Yutaka SAWAKI and Kiyoshi ISOGIMI Department of Mechanical Engineering, Mie Univ.,Kamihamacho1515, Tsu 514-8507,Japan

Key Words: AFRP, Aramide fiber, one bar method, sprit hopkinson bar method

\section{1 粕言}

FRP は金属や木材，あるいはコンクリートなどに代わる 新しい工業材料として発展する高強度, 高弾性な素材であ ることがよく知られている。 また耐熱性，耐食性の優れた 樹脂の開発により，それらの特性をもあわせもつようにな

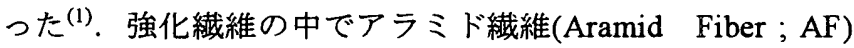
は，炭素繊維やガラス瀻維に比べて衝撃強度が高く，複合 材料とした場合，CFRP や GFRP と異なりアルミニウムに 類似した金属的延性挙動を示す特徽をもち，有機材料であ る点も含めて高分子系複合材料の強化材として注目を集め ている(2). そこで本研究では，衝撃負荷作用時における動 的引張応力ーひずみ関係を明らかにして，さらに大きな強 度を発揮することができる AFRP を開発する方向を探るこ とを目的とした (3). 本報ではアラミド瀻維を強化繊維とす る,アラミド長繊維プラスチックの動的引張特性を解明す るため one bar method ${ }^{(4)}$ を用い実験を行い，その動的引張特 性について検討を行った。

\section{2 実験原理}

本研究では one bar methodによって動的引張特性を調べ た。図 1 に one bar method の原理図を示す. one bar method では試験片を衝撃ブロックと出力棒の間に取り付け, 衝撃 ブロックに衝撃を与える。このとき試験片は高速引張り荷 重をうけ動的応力を生じる.この動的応力は出力棒中に伝 播するので棒中の応力波を測定して得られる. 出力棒は十 分長いので末端からの反射波が介入してくる前に測定が終 わる.

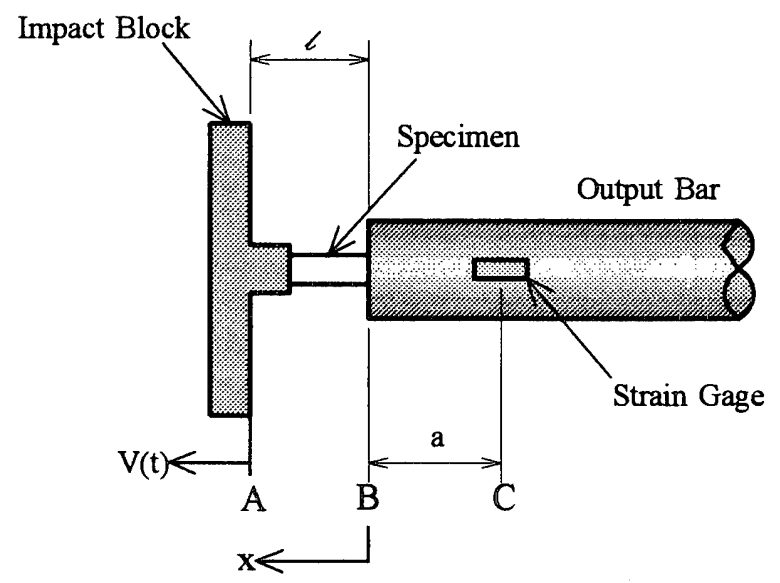

材料の公称応力 $\sigma(\mathrm{t})$ および公称ひずみ $\varepsilon(\mathrm{t})$ は

$$
\begin{aligned}
& \varepsilon(t)=\frac{1}{l} \int_{0}^{t}\left[V(\tau)-c \varepsilon_{g}\left(\tau+\frac{a}{c}\right)\right] d \tau \\
& \sigma(t)=\left(\frac{S_{0}}{S}\right) E_{0} \varepsilon_{g}\left(t+\frac{a}{c}\right)
\end{aligned}
$$

で与えられる，ここで $\ell:$ 試験片の長さ， $V(t)$ は衝撃ブロッ クの移動速度, $c$ : 出力棒の縦弾性波伝播速度, $E_{0}$ : 出力棒 のヤング率, $S_{0}$ : 出力棒の断面積, $S$ : 試験片の断面積, $\varepsilon$ ${ }_{g}(\mathrm{t})$ : 出力棒の $\mathrm{C}$ 点でのひずみ, $a$ : 出力棒に貼り付けたひ ずみゲージから出力棒先端までの距離である。この中で測 定すべき值は, 衝撃ブロックの移動速度 $V(t)$ と出力棒の点 $\mathrm{C}$ でのひずみ $\mathrm{g}_{\mathrm{g}}(\mathrm{t})$ 二つである. また材料中の縦弾性波伝 播速度 $c$ は材料のヤング率 $E_{0}$ と密度 $\rho$ を用いて次式で表さ れる(4).

$$
c=\sqrt{\frac{E_{0}}{\rho}}
$$

\section{3 実臨方法}

本研究における実験装置の概観を図 2 に示す.ここでは 衝撃ブロックにアルミを用い, 出力棒にアクリル樹脂(MA) の丸棒(長さ $1 \mathrm{~m}$, 直径 $20 \mathrm{~mm}$ )を用いた. 本実験で用いた アクリル樹脂(MA)の物性値を表 1 に示す.

Table.1 Properties of acrylic resin (MA)

\begin{tabular}{|c|c|c|}
\hline$E_{0}[\mathrm{Gpa}]$ & $\rho\left[\mathrm{kg} / \mathrm{m}^{3}\right]$ & $\mathrm{c}_{0}[\mathrm{~m} / \mathrm{s}]$ \\
\hline 3.1 & 1190 & 1614 \\
\hline
\end{tabular}

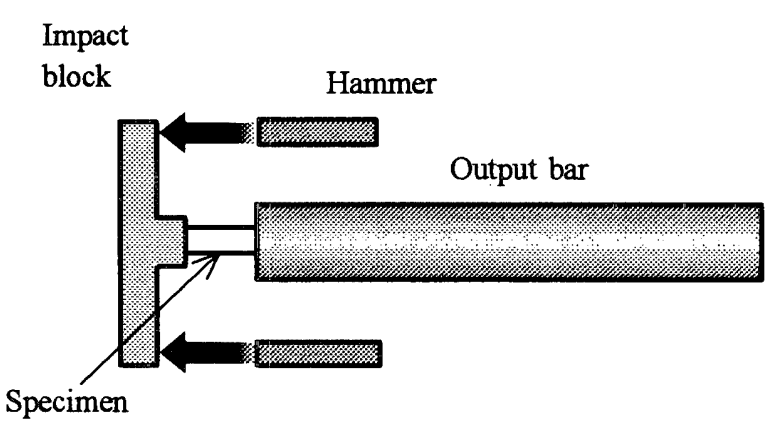

Fig.2 Experimental setup for impact tensile test

日本機械学会東海支部第53期総会講演会講演論文集（' 04. 3. 17-18） No. 043-1 
次に実験手順を示す、試験片の一端にアルミ製の衝撃ブ ロックを取り付け，他端を出力棒先端に固定する，振り子 式のハンマ(全長 $300 \mathrm{~mm}$ )で衝撃ブロックに衝撃力を加え, 出力棒先端から $30 \mathrm{~mm}$ の位置に貼り付けたひずみゲージ (共和製)で出力棒のひずみを測定した。また衝撃ブロック の移動速度 $\mathrm{V}(\mathrm{t})$ は，ハンマの移動速度と同一とみなし，八 ンマの速度をフォトインタラプタ装置により測定した。

\section{4 試医片}

本研究ではマトリックスに不飽和ポリエステル樹脂を， 強化繊維にアラミド長繊維を軸方向に含有する AFRP 試験 片を作成した。この AFRP 試験片に加えて，不飽和ポリエ ステル樹脂のみの試験片を比較対照のために製作，使用し た。本実験に使用した試験片形状を図 3 に示す。図に示す $\mathrm{X}, \mathrm{Y}, \mathrm{L}_{1} \sim \mathrm{L}_{5}$ の寸法を試験前に測定し, 断面積の変化を求め, ひずみを算出した。

以下に試験片の製作方法を示す．3 時間の真空引きによ って不純物及び気泡を取り除いた不飽和ポリエステルに硬 化剂(メチルエチルパーオキシドのジメチルフタレート溶 液)を $1 \mathrm{w} \%$ 混合し，アラミド長繊維を通してある内径 $4.5 \mathrm{~mm}$ の円筒に流し込み, 常温で 24 時間かけて硬化させ る. その後円筒をはずして定温乾燥機中(353k)で 3 時間ア フターキュアを行った後に徐冷し，供試試験片とした。

105
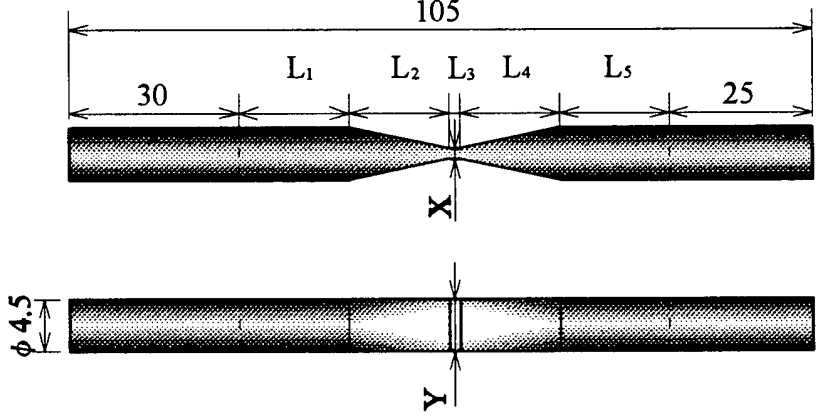

Fig.3 Dimensions of specimen

\section{5 実験結果及び考察}

実験において得られた種々の力学特性曲線を図 4〜6に 示す. 図 4 は時間に対する試験片の応力変化を示し, 図 5 は試験片の時間に対するひずみ変化を示す。図6には応力 ひずみ関係を示した。図 4 の応力一時間曲線ではアラミド 繊維を含有する試験片, マトリックスのみの試験片ともに 時間に対して若干上に凸の曲線を描いて増加している．ま たアラミド繊維を含有する試験片においては，マトリック スのみの試験片に比べ最大応力の面で勝っているのが分か る。図 5 のひずみ一時間曲線は, 両試験片共に時間に対し て直線的にひずみが増加している。これは試験片に対して ハンマの秤量が大きすぎるため, 試験片破断時のハンマの 速度変化が少なすぎるためであると考えられる．また図 6 に示す応力ーひずみ曲線では，アラミド繊維を含有する試 験片，マトリックスのみの試験片ともにひずみが増加する につれて，若干上に凸の曲線を描いて増加している。また アラミド繊維を含有する試験片ではマトリックスのみの試 験片に比べて応力に対するひずみが大きい，アラミド瀻維 を含有ことで吸収エネルギーの増加に加え，延性を付すこ とができたと考えられる。

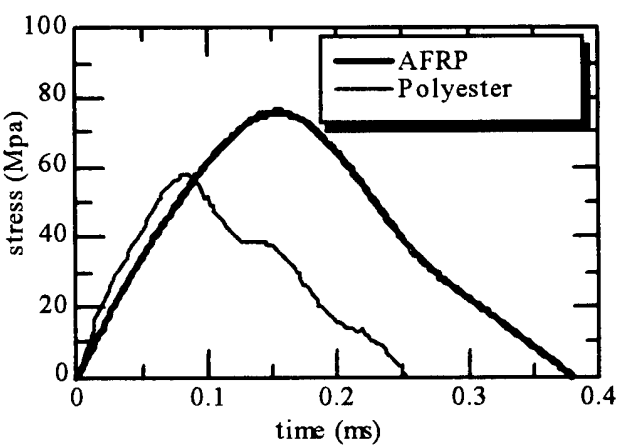

Fig.4 Curve of stress versus time

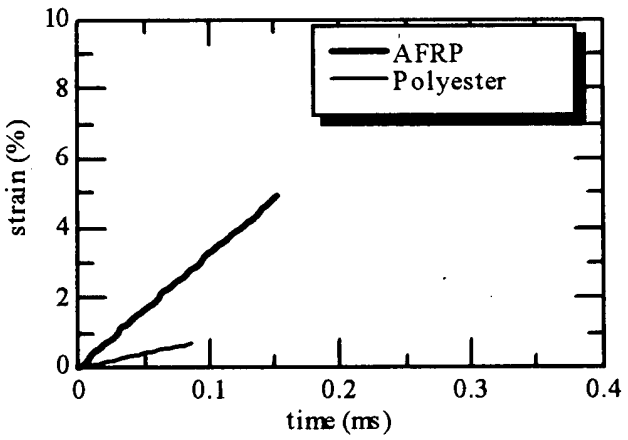

Fig. 5 Curve of strain versus time

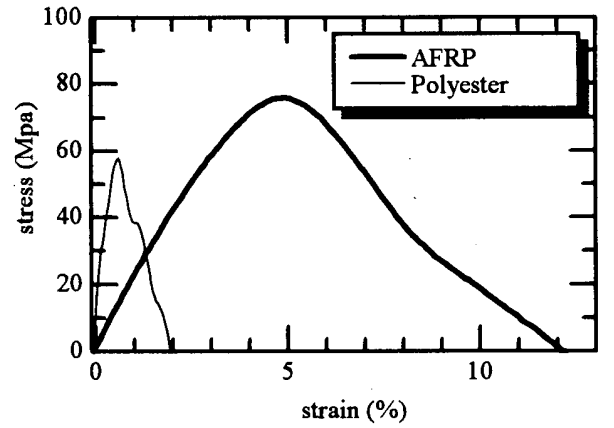

Fig.6 Stress-strain diagrams of AFRP and polyester

\section{6 結言}

以上より次のようにまとめられる.

・ one bar method を用いて実験を行うことにより， AFRP の応力ーひずみ線図を得ることができた.

・アラミド繊維を含有することで最大忘力, 吸収エネルギ 一を増加させ，延性を与えることができる．

・ ハンマの秤量を小さくすることで，より正確にひずみの 測定ができると考えられる.

\section{参考文获}

（1）田中良平，澤岡昭，石川欣三：未来を開く新素材，森 北出版

（2）海老原熊雄 : 新素材ハンドブック，集美堂

(3) Yang Wang, Yuanming Xia. A modified constitutiveequation for unidirectional composites under tensile impact and the dynamic tensile properties of KFRP, Composites Science and Technology, 60 (2000), pp.591-596

（4）河田幸三：材料力学, 朝倉書店 